\title{
ROOSTING AND NESTING HABITS OF FREE RANGING INDIAN PEAFOWL (PaVo CRISTATUS) IN SOUTHERN TAMIL NADU
}

\author{
K.S.Subramanian ${ }^{1}$ and Mathew C. John ${ }^{2}$ \\ ${ }^{1}$ Veterinary University Training and Research Centre, Tiruneiveli, Tamil Nadu, India. \\ ${ }^{2}$ Professor and Head, Department of Wildlife Sciences, Madras Veterinary College, Chennai, Tamil Nadu 600007, India.
}

\begin{abstract}
Roosting and nesting habits of free ranging Indian Peafowl (Pavo cristatus) were studied for a period of one year in southern Tamil Nadu. Peacocks were observed to be both solitary and communal roosters while the peahens were observed to have only communal roosting habits. Peafowls were observed to roost when the light intensity of the habitat dropped below 8 lux. Various tree species used by the peafowl for roosting are presented along with a note on nesting season, nesting preference and clutch size. In Tirunelveli, December to March was found to be the nesting season with the peahens preferring Prosopis bushes. The observed clutch size (mean) was 4.4.
\end{abstract}

\section{Key words}

Pavo cristatus, Indian Peafowl, roosting, nesting, southern Tamil Nadu

\section{Introduction}

The Indian Peafowl (Pavo cristatus) is essentially a denizen of humid tropical forests of the country (Mukherjee, 1979) but it also uses wet tracts, thick beds of seeds and grass, clusters of trees and open grassy space along fresh waters. This report details some observations on the roosting and nesting habits of free ranging peafowls in southern Tamil Nadu.

\section{Methods}

The study on roosting behaviour was carried out for a period of one year from April 1999 to March 2000 at two places in southern Tamil Nadu viz., Deer Park, Tirunelveli $\left(77^{\circ} 45^{\prime}\right.$ E, 8 $\left.{ }^{0} 44^{\prime} \mathrm{N}\right)$, which is a Reserve Forest harbouring Peafowl in an area of 100ha and Vivekananda Kendra, Kanyakumari (77030' E, 80 $5^{\prime}$ N), which maintains a semi-feral population of peafowl in an area of 50ha. The roosting habits of peafowl in both the study areas were observed for 320 hours. The light intensity of the habitat in relation to the roosting activity of 20 peafowl at Deer Park and 15 peafowl at Vivekananda Kendra were recorded using a Lux meter (Lx-102, Light meter, Lutran Ltd). The tree species used by peafowl for roosting were identified and recorded. Accidental observations on the nesting behaviour such as nesting season, pattern and nesting materials used by $P$. cristatus was noted at Deer Park, Tirunelveli, through out the study period.

\section{Observations and Results Roosting}

Majority of the adult males roosted alone or together with one or two adult males at Deer Park where as at Vivekananda Kendra, they were found to roost with females and sub-adult males in small groups on the same tree. Majority of the peahens roosted together in small groups of 3-4 along with sub-adult males in both the study areas, while the peahens with young ones roosted on the ground in dense thorny bushes. At the Deer Park, the peafowls preferentially roosted on Tamarind (Tamarindus indicus), Vagai (Albizzia lebbeck), Neem (Azadirachta indica), Usilai (Albizzia amara), Palmyra (Borrassus flabellifer) and less frequently on Manjanathi (Morinda tinctoria) and Velvelam (Acacia leucophloea) trees. The height of these roosting trees varied from $8-12 \mathrm{~m}$. Some of the peafowls at the Deer Park roosted on telecommunication pylons and an adult peacock was observed to roost regularly on a palmyra tree through out the study period.

At Vivekananda Kendra, coconut palms (Cocos nucifera) were primarily used for roosting while Tamarind, Neem, Mango (Mangifera indica) and Umbrella thorn (Acacia planifrons) were observed to be the second choice. The height of the roosting trees varied from $8-14 \mathrm{~m}$. In both the study areas peafowl preferred to roost primarily on tall trees $(>8 \mathrm{~m})$ with thick branches. Whenever peafowls roosted on trees with dense foliage such as tamarind and neem they preferred the highest branches where

* Part of M.V.Sc. thesis submitted by KSS to TANUVAS, Chennai 
as in trees with less foliage such as vagai, usilai etc., they roosted on lower branches also. On leafy trees having several thick branches, the peafowl first rested on a lower branch and then moved to the final roosting site. In both the study areas, the peafowls were observed to roost when the light intensity of the habitat dropped below 8 lux.

\section{Nesting}

At the Deer Park, a total of five nests were sighted during December to February. The sightings were accidental which was noted while walking through the study area. In certain cases the disturbed brooding hens flew from the nests. Free ranging peahen preferred Prosopis bushes for nesting.

During the initial days of incubation the peahen was observed to fly far away when observers approached its nest but as the incubation advanced it was very hesitant to move. It only went for a short distance and returned soon after the observers left the vicinity. During the first week of March two precocial chicks with the hen were sighted in the Deer Park area. The clutch size of the five nests observed varied from 3-6 eggs with a mean of 4.4 (Table 1). The eggs were drab to pale brown in colour, smooth with thick glossy shell closely pitted over the surface.

\section{Discussion}

Pavo cristatus are both communal and solitary roosters (Trivedi, 1993). The present study also showed the same result. One probable reason for the communal roosting habit of peacocks at Vivekananda Kendra may be their vulnerability for predation by feral dogs in that area. Communal roosting facilitate the birds to detect the predators easily. On trees with dense foliage, they preferred to roost on the highest branches. These observations resemble the findings of Yasmin (1994). Hence, it could be attributed that the selection of roosting branch by peafowl depends on the clarity of vision it provides of the surroundings.

Johnsingh and Murali (1978) opined that some of the roost trees were traditional sites to which peafowl return every night. This coincided with the present findings, where in one adult peacock was observed to roost regularly on a palmyra tree at the Deer

Table 1. Clutch size and Nest morphometey of Peafowl

\begin{tabular}{lllll}
\hline Nest & Clutch & $\begin{array}{l}\text { Diameter } \\
\text { (cm) }\end{array}$ & $\begin{array}{l}\text { Radius } \\
\text { (cm) }\end{array}$ & $\begin{array}{l}\text { Nest circumference } \\
\text { (cm) }\end{array}$ \\
\hline 1 & 4 & 44 & 22 & 138 \\
2 & 4 & 48 & 24 & 151 \\
3 & 3 & 40 & 20 & 126 \\
4 & 6 & 52 & 26 & 163 \\
5 & 5 & 48 & 24 & 151 \\
Mean & 4.4 & 46 & 23 & 146 \\
\hline
\end{tabular}

Park through out the study period. The inmates of the Vivekananda Kendra had noticed two incidences of predation of peafowl by feral dogs during 1998, but such an incident was not observed during the study period. Peafowls went for roosting when the light intensity of the habitat dropped below 8 lux since it was very difficult for the bird to locate predators in lower light intensities.

Ali and Ripley (1987) reported that the nesting season of peafowl was from January to October and it usually concides with monsoon. In the present study December to March was observed to be the nesting season for free ranging peahen at the Deer Park, Tirunelveli. In Aligarh region, the pre-breeding season of peafowl starts from March to June, followed by the breeding season from July to September and a non-breeding season from November to February (Yasmin, 1995). In southern India it usually coincides with the Northeast monsoon (OctoberDecember). Johnsingh and Murali (1978) reported that the breeding period of peafowl in southern Tamil Nadu starts by November, followed by a post-breeding (nesting) period from November to March which is similar to the observations recorded in this study.

Budgey (1994) and Gardiner (1996) opined that peahens usually made their nests in isolated sites in thick bushes and laid their eggs in protective places if predation trend was high. In the present study the nests were built using dried grasses intermingled with small dry twigs of Prosopis which effectively concealed their nests.

\section{Acknowledgement}

The authors thank the Tamil Nadu State Forest Department for granting permission to carry out this study.

\section{References}

Ali, S. and S.D. Ripley (1987). Hand Book of Birds of India and Pakistan. Oxford University Press, Bombay, 126 pp.

Budgey, H.V. (1994). Parental strategies of Indian peahen. Ph.D. Thesis, Open University, U.K. (Unpublished).

Gardiner, T.P. (1996). Peafowl - their conservation, breeding and management. World Pheasant Association, Reading, U.K.

Hill, D.A. and P.A. Robertson (1988). The Pheasant: Ecology, Management and Conservation. BSP Professional Books, Oxford, $281 \mathrm{pp}$.

Johnsingh, A.J.T. and S. Murali (1978). The ecology and behaviour of Indian peafowl (Pavo cristatus) of Injar. Journal of the Bombay Natural History Society 75: 1069-1079.

Mukherjee, A.K. (1979). Peacock - Our National Bird. Government of India Press, New Delhi.

Trivedi, P. (1993). Habitat selection by Indian peafowl in Gir Forest. M. Sc., Dissertation, Saurashtra University (Unpublished) pp.36. Yasmin, S. (1994). Characteristics of trees used for roosting by blue peafowl in Aligarh district, India. Annual Review of the World Pheasant Association 49: 57-63. 